\title{
Mechanistic insights into functional characteristics of native crotamine
}

\author{
Daniel Batista da Cunha a, Ana Vitória Pupo Silvestrini a , Ana Carolina Gomes da Silva a \\ Deborah Maria de Paula Estevam ${ }^{\text {b}}$, Flávia Lino Pollettini ${ }^{\mathrm{b}}$, Juliana de Oliveira Navarro a \\ Armindo Antônio Alves a , Ana Laura Remédio Zeni Beretta a, \\ Joyce M. Annichino Bizzacchi ${ }^{c}$, Lilian Cristina Pereira ${ }^{d}$, Maurício Ventura Mazzi a, * \\ a Graduate Program in Biomedical Sciences Hermínio Ometto University Center, UNIARARAS, 7 Av. Dr. Maximiliano Baruto, 500, CEP 13607-339, Araras, SP, \\ Brazil \\ ${ }^{\mathrm{b}}$ Graduate Program in Agrarian and Veterinary Sciences, State University Paulista Júlio de Mesquita Filho-UNESP, Jaboticabal, SP, Brazil \\ ${ }^{\mathrm{c}}$ Blood Hemostasis Laboratory, Faculty of Medical Sciences, State University of Campinas, Campinas, SP, Brazil \\ ${ }^{\mathrm{d}}$ Department of Bioprocesses and Biotechnology, Faculty of Agronomic Sciences, State University Paulista Júlio Mesquita Filho-UNESP, Botucatu, SP, Brazil
}

\section{A R T I C L E I N F O}

\section{Article history:}

Received 4 October 2017

Received in revised form 6 March 2018

Accepted 20 March 2018

Available online 21 March 2018

\section{Keywords:}

Crotalus durissus terrificus

Crotamine

Antimicrobial

Platelet aggregation

Mitochondrial dysfunction

\begin{abstract}
A B S T R A C T
The chemical composition of snake venoms is a complex mixture of proteins and peptides that can be pharmacologically active. Crotamine, a cell-penetrating peptide, has been described to have antimicrobial properties and it exerts its effects by interacting selectively with different structures, inducing changes in the ion flow pattern and cellular responses. However, its real therapeutic potential is not yet fully known. Bearing in mind that crotamine is a promising molecule in therapeutics, this study investigated the action of purified molecule in three aspects: I) antibacterial action on different species of clinical interest, II) the effect of two different concentrations of the molecule on platelet aggregation, and III) its effects on isolated mitochondria. Crotamine was purified to homogeneity in a single step procedure using Heparin Sepharose. The molecular mass of the purified enzyme was $4881.4 \mathrm{Da}$, as determined by mass spectrometry. To assess antibacterial action, changes in the parameters of bacterial oxidative stress were determined. The peptide showed antibacterial activity on Escherichia coli (MIC: $2.0 \mu \mathrm{g} / \mu \mathrm{L}$ ), Staphylococcus aureus (MIC: $8-16 \mu \mathrm{g} / \mu \mathrm{L}$ ) and methicillin-resistant Staphylococcus aureus (MIC: $4.0-8.0 \mu \mathrm{g} / \mu \mathrm{L}$ ), inducing bacterial death by lipid peroxidation and oxidation of target proteins, determined by thiobarbituric acid reactive substances and sulfhydryl groups, respectively. Crotamine induced increased platelet aggregation (IPA) at the two concentrations analyzed ( 0.1 and $1.4 \mu \mathrm{g} / \mu \mathrm{L})$ compared to ADP-induced aggregation of PRP. Mitochondrial respiratory parameters and organelle structure assays were used to elucidate the action of the compound in this organelle. The exposure of mitochondria to crotamine caused a decrease in oxidative phosphorylation and changes in mitochondrial permeability, without causing damage in the mitochondrial redox state. Together, these results support the hypothesis that, besides the antimicrobial potential, crotamine acts on different molecular targets, inducing platelet aggregation and mitochondrial dysfunction.
\end{abstract}

๑) 2018 Elsevier Ltd. All rights reserved.

\section{Introduction}

Snake venoms are a promising source of biologically active substances that have specific mechanisms of action under different molecular targets (Koh et al., 2006). The biological effects caused by

\footnotetext{
* Corresponding author.

E-mail address: maumazzi@uniararas.br (M.V. Mazzi).
}

the Crotalus durissus terrificus venom are attributed to the actions of various neurotoxins such as crotoxin, convulxine, gyroxine and crotamine, as well as peptides and enzymes, including L-aminoxidase, thrombin-like phosphodiesterases, tissue-type kallikrein NAD-hydrolase, disintegrins, natriuretic peptides, growth factors, C-type lectin, and cysteine-rich secretory proteins (Bercovici et al., 1987; Bjarnason and Fox, 1994).

Crotamine, a polypeptide with an approximate molecular mass of $4.8 \mathrm{kDa}$, induces structural damage to skeletal muscle fibers with 
consequent myotoxicity and myonecrosis (Gonçalves and Arantes, 1956; Cameron and Tu, 1978; Peigneur et al., 2012). These effects are related to changes in membrane potential and the influx of sodium and potassium ions, changes in mitochondrial calcium homeostasis, and degeneration of myofibrils, without damage to the sarcolemma or the transverse tubules (Cheymol et al., 1971; Chang and Tseng, 1978; Gutiérrez and Cerdas, 1984; Ownby et al., 1988; Fletcher et al., 1996) and also is able to blocker Kv1.3 channel, such as mitoKv1.3 in mitochondrial inner membrane (Peigneur et al., 2012; Szabó et al., 2008).

The pharmacological activities of crotamine have been studied previously, including the induction of acetylcholine and dopamine release in striated tissue (Camillo et al., 2001) and of histamine into mast cells (Mancin et al., 1997), analgesia (Mancin et al., 1998), insulin secretion of $\beta$-pancreatic cells (Toyama et al., 2000), and stimulation of phagocytic activity of macrophages from the induction of nitric oxide (iNOs) and TNF- $\alpha$ via p38 and nFk-B (Lee et al., 2016). Crotamine was also shown to increase memory persistence in mice with no changes in mood, anxiety and locomotion (Vargas et al., 2014). In addition, crotamine has been shown to have a heterogeneous cytotoxic profile on different microorganisms, and structural and/or genetic similarities with antimicrobial peptides, such as HBD-2 and $\beta$-defensive peptides. Moreover, the toxin has shown important effects on cellular metabolism involving different signaling pathways, and due to its cellular penetration capacity, it has been studied as a peptide mediator for the release of drugs, peptides and proteins, and as an antitumor substance (Kerkis et al., 2004, 2017; Hayashi et al., 2008, 2012; Nascimento et al., 2007; Pereira et al., 2011; Rodrigues et al., 2013).

The cytotoxic effects of crotamine have been demonstrated in vivo and in vitro using tumor cell lines, which allow understanding how the molecule is capable of altering cellular homeostasis including damage to cytoplasmic organelles such as lysosomes and mitochondria (Nascimento et al., 2012). Due to its characteristics, crotamine has been recognized as a promising molecule in several biological processes. To better understand the toxicity of crotamine and its probable antibacterial action, we evaluated its effect on the oxidative stress in bacteria of clinical interest. Additionally, we studied the effects of crotamine on platelet aggregation and mitochondrial bioenergetics.

\section{Materials and methods}

\subsection{Reagents and venom}

Crotalus durissus terrificus venom, which is yellowish in color, was purchased from Koemitã Me (Mococa, SP, Brazil). HeparinSepharose FF and HiPrep 26/10 Desalting column were purchased from Amersham Life Science, Inc. The Müeller-Hinton agar was purchased from Himedia (India) and the platelets were from healthy donors. EGTA, sucrose, rotenone, succinate, ADP, cyclosporin, ruthenium red, N-ethylmaleimide, butylated hydroxytoluene, thiobarbituric acid and 5,5'-dithiobis-2-nitrobenzoic acid (DTNB) was purchased from Sigma Chem. Co. Alfa-cyano-4hydroxy cinnamic acid (HCCA) and Peptide calibration standard II were purchased from Bruker Daltonics. TFA, Acetonitrile from JT Baker. All of the other reagents used in this study were of analytical grade and purchased from Sigma Chem. Co, Merck and/or Sinapse Biotechnologia.

This research was approved by the Committee of Ethics in Research and Scientific Merit of the Hermínio Ometto University Center, UNIARARAS (process $n^{\circ}$ 833/2015 and 014/2017).

\subsection{Purification of crotamine}

C. durissus terrificus crude venom ( $0.1 \mathrm{~g})$ was applied to HeparinSepharose FF (HiTrap, heparin (HP), $5 \mathrm{~mL}$ ) column that had previously been equilibrated with $0.01 \mathrm{M}$ sodium phosphate, $\mathrm{pH}$ 7.0. The protein was eluted in linear gradient of $\mathrm{NaCl}(0-1.5 \mathrm{M})$ at a flow rate of $2.5 \mathrm{~mL} / \mathrm{min}$, and $3 \mathrm{~mL}$ fractions were collected. The eluted fraction containing crotamine was concentrated in an ALPHA 2-4 LD plus Freeze-Dryer and $30 \mathrm{mg}$ of the fraction were applied to HiPrep 26/10 Desalting column equilibrated with $0.05 \mathrm{M}$ ammonium bi-

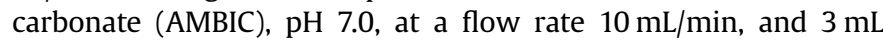
fractions were collected. Chromatography was performed using the ÄKTAprime and liquid chromatography system (GE Healthcare). Next, crotamine was subjected to identification and functional characterization. All purification and isolation procedures were performed at room temperature.

\subsection{Identification of crotamine}

The identification of crotamine was determined by mass spectrometry. A Coomassie Brilliant Blue-stained crotamine band (approximately $2 \mu \mathrm{g} / \mathrm{spot}$ ) was cut out of the polyacrylamide gel (13\%) and "in-gel" digested for peptide mass fingerprinting and for internal sequence determination. Five micrograms of isolated crotamine were reduced in $10 \mathrm{mM}$ DTT, alkylated in $50 \mathrm{mM}$ iodoacetamide and then trypsinized in $20 \mathrm{ng} / \mu \mathrm{L}$ trypsin after gel electrophoresis, according to the protocol reported by Shevchenko et al. (1996), with some modifications. Tryptic fragmentations of the peptide were scored by the cleavage of peptide bond, and charges on C-terminus (y ions) and N-terminus (b ions) were generated. Peptide identification was performed in a liquid chromatography-tandem mass spectrometer coupled to a high performance liquid chromatographer using a C18 nanocolumn (LCMS/MS Q-TOF PREMIERTM). The resulting spectra were analyzed using Mascot (Matrix Science) in the NCBI nr protein databases, with carbamidomethylation as the fixed modification. The similarity between peptide sequences was assessed with BLAST.

The molecular mass, as well as, profiling of native crotamine was determined through matrix-assisted laser desorption/ionization (MALDI-TOF/TOF) by using a Bruker Ultraflextreme equipment (Bruker Daltonics). Five micrograms of crotamine was diluted with alpha-cyano-4-hydroxy cinnamic acid (HCCA) in a saturated solution of acetonitrile containing $0.1 \%$ trifluoroacetic acid: deionized water $(3: 7 \mathrm{v} / \mathrm{v})$. The parameters used to obtain the spectra were: 1000 laser shots/spectra, PIE (Pulsed ion extraction) of $100 \mathrm{~ns}$, positive mode, laser frequency of $1000 \mathrm{~Hz}$ and negative mode of ionization. The voltage (IS1 and IS2) applied were $20 \mathrm{kV}$ and $18.05 \mathrm{kV}$ respectively. The voltage reflector mode (RV1 and RV2) of $21.3 \mathrm{kV}$ and $10.7 \mathrm{kV}$ respectively were used. For external calibration, a Bruker peptides standard II were used.

\subsection{Evaluation of the antibacterial action of crotamine}

\subsubsection{Determination of bacterial oxidative stress}

The antibacterial action was evaluated by the microdilution method according to the Clinical and Laboratory Standards Institute (Wayne, 2007) for the following bacterial species of clinical interest: Escherichia coli (ATCC 25922), Pseudomonas aeruginosa (ATCC 27853), Staphylococcus aureus (ATCC 25923) and ORSA - oxacillinresistant Staphylococcus aureus (ATCC 33591). Bacterial cultures were spiked into Brain Heart Infusion Broth (BHI) enriched medium and incubated at $37^{\circ} \mathrm{C}$ for $24 \mathrm{~h}$. After, the microbial density was adjusted to approximately $10^{8} \mathrm{CFU} / \mathrm{mL}$. Then, $50 \mu \mathrm{L}$ of sterile $\mathrm{BHI}$ culture medium, $50 \mu \mathrm{L}$ of the diluted bacterial suspension at $10^{6} \mathrm{CFU} / \mathrm{mL}$ and $100 \mu \mathrm{L}$ of crotamine at increasing concentrations 
(2.0-16 $\mu \mathrm{g} / \mu \mathrm{L})$ were added to a 96-well plate. A negative control of $100 \mu \mathrm{L}$ of sterile ultrapure $\mathrm{H}_{2} \mathrm{O}$ and a positive control of $100 \mu \mathrm{L}$ of levofloxacin $(30 \mu \mathrm{g} / \mu \mathrm{L})$ were submitted to the same conditions. Plates were incubated at $37^{\circ} \mathrm{C}$ for $24 \mathrm{~h}$ and inhibition of bacterial growth was determined spectrophotometrically on a Biotek ELX 800 microplate reader $\left(\lambda_{490 \mathrm{~nm}}\right)$ at 0 and $24 \mathrm{~h}$. The lowest concentration capable of inhibiting bacterial growth was considered the minimum inhibitory concentration (MIC).

Bacterial oxidative stress was determined by the levels of thiobarbituric acid reactive species (TBARS) according to the methodology described by Esterbauer and Cheeseman (1990). The concentration of MDA-TBA produced was determined spectrophotometrically $\left(\lambda_{535 \mathrm{~nm}}\right)$ and reported in $\mathrm{nM} / \mathrm{mg}$ protein, using the molar extinction coefficient $\left(\varepsilon=1.56 \times 10^{5} \mathrm{M}^{-1} \mathrm{~cm}^{-1}\right)$. The sulfhydryl groups were determined by the spectrophotometric method $\left(\lambda_{412}\right)$ as described by Faure and Lafond (1995) by reaction with 5,5'dithiobis-2-nitrobenzoic acid (DTNB) and the levels calculated using the molar extinction coefficient $\left(\varepsilon=13600 \mathrm{M}^{-1} \mathrm{~cm}^{-1}\right)$.

\subsection{Effect of crotamine on platelet aggregation}

A pool of blood samples obtained of ten human health volunteers, previously treated with $3.2 \%$ sodium citrate, were centrifuged at $850 \mathrm{rpm}$ for $15 \mathrm{~min}$ and at $3500 \mathrm{rpm}$ to obtain platelet-rich plasma (PRP). The PRP concentration was adjusted in an aggregometer $\left(5 \times 10^{5}\right.$ platelets $\left./ \mathrm{mL}\right)$ and the absence of platelet aggregation was confirmed. Two different concentrations of crotamine and crude venom $(0.1$ and $1.4 \mu \mathrm{g} / \mu \mathrm{L})$ were incubated with $440 \mu \mathrm{L}$ of PRP and the reaction was monitored for $5 \mathrm{~min}$ in a Chrono-Log Model 700 Whole Blood /Optical Lumi-Aggregometer ( $\lambda_{935}$ $955 \mathrm{~nm})$. The results transcribed by the Aggro /Link 8 software were compared with the positive control (ADP $1 \mathrm{nM} / \mu \mathrm{L}$ ) and the negative control (PRP only) under the same conditions. Results are reported as percentage of platelet aggregation over a 5-min time period.

\subsection{Mitochondrial assays}

\subsubsection{Animals}

Male Wistar rats weighing 180-220 g were used. The Committee for Experimental Animal Care and Use of the Hermínio Ometto University Center, Brazil, approved all the experimental procedures (FHO-UNIARARAS, protocol 014-2017). Animals were kept under a $12 \mathrm{~h}$ light:dark cycle, at an ambient temperature of $24 \pm 2{ }^{\circ} \mathrm{C}$, with water and food provided ad libitum.

\subsubsection{Mitochondria isolation}

The animals were euthanized and their livers (10-15 g) were immediately removed, sliced into a $50 \mathrm{~mL}$ medium containing $250 \mathrm{mM}$ sucrose, $1 \mathrm{mM}$ EGTA, and $10 \mathrm{mM}$ HEPES-KOH, $\mathrm{pH}$ 7.2, and homogenized three times in a Potter-Elvehjem homogenizer for $15 \mathrm{~s}$, with $1 \mathrm{~min}$ intervals between each. Rat liver mitochondria were isolated by standard differential centrifugation (Pedersen et al., 1978). Homogenates were centrifuged at $580 \mathrm{~g}$ for $5 \mathrm{~min}$; the supernatant was centrifuged again at $10,300 \mathrm{~g}$ for $10 \mathrm{~min}$. The pellets were suspended in $10 \mathrm{~mL}$ of medium containing $250 \mathrm{mM}$ sucrose, $0.3 \mathrm{mM}$ EGTA, and $10 \mathrm{mM}$ HEPES-KOH, pH 7.2, and finally centrifuged at $3400 \mathrm{~g}$ for $15 \mathrm{~min}$. The mitochondrial pellet was suspended in $1 \mathrm{~mL}$ of medium containing $250 \mathrm{mM}$ sucrose and $10 \mathrm{mM}$ HEPES-KOH, pH 7.2, and used within $3 \mathrm{~h}$. During all the procedures the mitochondria were maintained at $4{ }^{\circ} \mathrm{C}$, and the mitochondrial protein content was determined by the biuret reaction.

\subsubsection{Mitochondrial respiratory rate}

Mitochondrial respiration was polarographically monitored on an oxygraph (Hansatech, Norfolk, England) equipped with a Clarktype oxygen electrode (Chance and Willians, 1956). The mitochondria ( $1 \mathrm{mg}$ of protein/mL) were incubated in $1 \mathrm{~mL}$ of the standard medium containing $125 \mathrm{mM}$ sucrose, $65 \mathrm{mM} \mathrm{KCl}, 10 \mathrm{mM}$ HEPES-KOH, $0.5 \mathrm{mM}$ EGTA and $10 \mathrm{mM} \mathrm{K}_{2} \mathrm{HPO}_{4}$, pH 7.2, at $30{ }^{\circ} \mathrm{C}$. Glutamate + malate and potassium succinate at $5 \mathrm{mM}$ (added with $2.5 \mu \mathrm{M}$ rotenone) were used as the oxidizable substrate for complexes I and II of the respiratory chain, respectively. The state III of the phosphorylation was initiated with $400 \mathrm{nmol}$ of ADP for all assays, and crotamine was added at the time of testing (Cain and Skilleter, 1987).

\subsubsection{Mitochondrial swelling}

Mitochondrial swelling was estimated from the decrease in apparent turbidity at $540 \mathrm{~nm}$ measured with a spectrophotometer (Thermo Fisher Scientific Evolution ${ }^{\mathrm{TM}} 300$ UV-Vis). The mitochondrial suspension $(0.4 \mathrm{mg}$ protein $/ \mathrm{mL})$ was incubated with the standard reaction medium plus $10 \mu \mathrm{M} \mathrm{Ca}^{2+}, 2.5 \mu \mathrm{M}$ rotenone, and $5 \mathrm{mM}$ succinate, at $30^{\circ} \mathrm{C}$. Kinetics evaluation was performed for 10 min (Lemaster et al., 1987) while different concentrations of crotamine were added to analyze mitochondrial swelling. To better understand the mechanisms that trigger the process, $1 \mu \mathrm{M}$ cyclosporine A (CsA), $0.5 \mu \mathrm{M}$ and $25 \mu \mathrm{M}$ ruthenium red (RR), $25 \mu \mathrm{M} \mathrm{N}$ ethylmaleimide (NEM) and $25 \mu \mathrm{M}$ butylated hydroxytoluene (BHT) were used as modulators of the process. Crotamine $(1000 \mu \mathrm{g} / \mathrm{mL})$ was added to the standard reaction medium after the modulators at the time of testing (Lemasters et al., 1987).

\subsubsection{Mitochondrial redox state}

Lipid peroxidation of the mitochondrial membrane (LPO assay) was estimated from malondialdehyde (MDA) generation (Buege and Aust, 1978). The mitochondrial suspension (1 $\mathrm{mg}$ of protein in $1 \mathrm{~mL}$ ) was incubated with $50 \mu \mathrm{M} \mathrm{FeSO}_{4}$ plus $2 \mathrm{mM}$ sodium citrate at $37^{\circ} \mathrm{C}$. After $30 \mathrm{~min}, 1 \mathrm{~mL}$ of $1 \%$ thiobarbituric acid (TBA, prepared in $50 \mathrm{mM} \mathrm{NaOH}$ ), $0.1 \mathrm{~mL}$ of $10 \mathrm{M} \mathrm{NaOH}$ and $0.5 \mathrm{~mL}$ of $20 \% \mathrm{H}_{3} \mathrm{PO}_{4}$ were added, followed by incubation for $20 \mathrm{~min}$ at $85^{\circ} \mathrm{C}$. The MDA-TBA complex was extracted with $2 \mathrm{~mL}$ of $n$-butanol and absorbance was measured at $\lambda_{535 \mathrm{~nm}}$. As a positive control, hydrogen peroxide (3\%) was used. MDA concentration was reported as $\mathrm{ng} / \mathrm{mg}$ of protein calculated from $\varepsilon=1.56 \times 10^{5} \mathrm{M}^{-1} \mathrm{~cm}^{-1}$ (Jocelyn, 1987; Devienne et al., 2007).

For quantification of sulfhydryl groups, the mitochondrial homogenate $(1 \mathrm{mg} / \mathrm{mL})$ was mixed with $5 \%$ perchloric acid, and the precipitate was resuspended with $1 \mathrm{~mL}$ of Tris-EDTA buffer $(\mathrm{pH}$ 8.0). As negative control, the same conditions were used without the addition of the peptide, and for the positive control, hydrogen peroxide (3\%) was used. The produced amount of sulfhydryl groups in proteins was determined spectrophotometrically $\left(\lambda_{412 \mathrm{~nm}}\right)$ after addition of $0.2 \mathrm{mM} / \mathrm{L}$ DTNB and calculated using the molar extinction coefficient $\left(\varepsilon=13600 \mathrm{M}^{-1} \mathrm{~cm}^{-1}\right)$.

\subsection{Statistical analysis}

The data from the antimicrobial and platelet aggregation assays were assessed by the Kolmogorov-Smirnov normality test, which confirmed that data was parametric. Therefore, the Student's t-test was used to compare each experimental group with the control group. For the mitochondrial assays, data were subjected to analysis of variance (ANOVA), followed by Dunnett's test for multiple comparisons. The data are presented in means $\pm S D$ or means \pm SEM. A $p<0.05$ indicates significant difference between the analyzed samples. Graphs and statistical analysis were performed in GraphPad Prism 5.1 software. 


\section{Results}

\subsection{Purification and identification of crotamine}

To assess the effects of crotamine on different biological systems, the molecule was isolated by bioaffinity chromatography done in one step in a Heparin Sepharose FF column (Fig. 1A). Crotamine identity and molecular mass were confirmed by LC-MS/ MS Q-TOF PREMIER and MALDI-TOF/TOF mass spectrometric analysis. Three internal peptide fragments (ICIPPSSDFGK; ICIPPSSDFGKMDCR, and EKICIPPSSDFGK) determined by mass spectrometry, confirmed the molecular identity (Fig. 2A). Additionally, the purified peptide presented an experimental molecular mass of 4881.449 Da (Fig. 2B).

\subsection{Bacterial oxidative stress induced by crotamine}

The results demonstrate a heterogeneous response pattern depending on the sensitivity of each microorganism, Escherichia coli (ATCC 25922), Pseudomonas aeruginosa (ATCC 27853), Staphylococcus aureus (ATCC 25923) and methicillin-resistant Staphylococcus aureus - MRSA (ATCC 33591) (Fig. 3). After $24 \mathrm{~h}$ incubation the species most susceptible to crotamine showed a growth reduction with concentrations between 2.0 and $16.0 \mu \mathrm{g} / \mu \mathrm{L}$ for E. coli, 8.0 and $16.0 \mu \mathrm{g} / \mu \mathrm{L}$ for S. aureus and $4.0-16.0 \mu \mathrm{g} / \mu \mathrm{L}$ for ORSA. The MIC determined for susceptible species was $16 \mu \mathrm{g} / \mu \mathrm{L}$ after $24 \mathrm{~h}$ of incubation (Fig. 3A, C, D). However, P. aeruginosa showed resistance at all concentrations of crotamine used (Fig. 3B). Additionally, except for $P$. aeruginosa, oxidative stress was observed in all other species, evidenced by the high levels of TBARS and sulfhydryl groups (-SH) (Fig. 4A-H).

\subsection{Effect of crotamine on platelet aggregation}

After 5-min treatment of platelet rich plasma $\left(5 \times 10^{5}\right.$ platelets/ $\mathrm{mL})$ with the lowest concentration $(0.1 \mu \mathrm{g} / \mu \mathrm{L})$ of crotamine, platelet aggregation was induced at $\sim 96 \%$. Treatment with the highest concentration induced $100 \%$ platelet aggregation, more than with

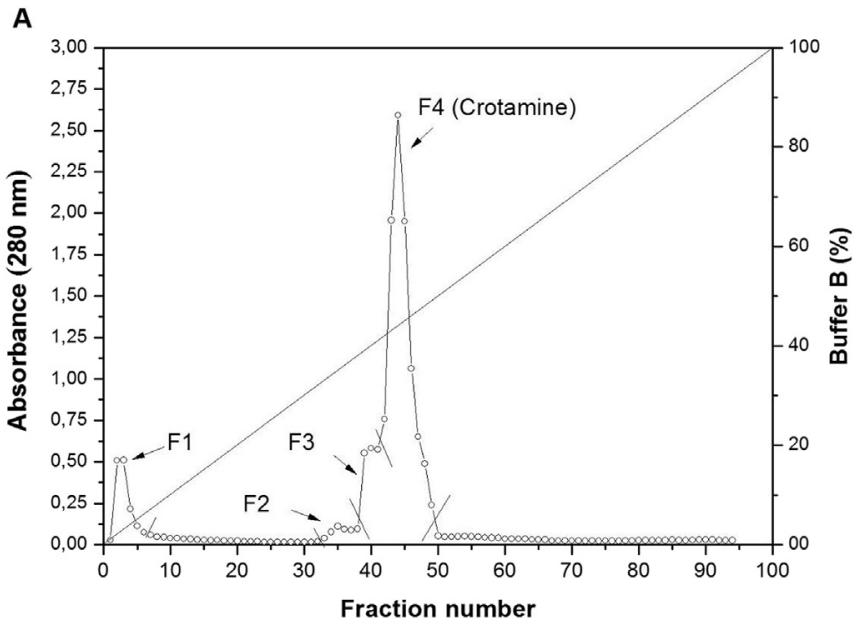

Fig. 1. Purification and isolation of crotamine. (A) Affinity chromatography of the crude venom of Crotalus durissus terrificus on Heparin Sepharose column (HiTrap, heparin (HP), $5 \mathrm{~mL}$ ), which had been previously equilibrated in $0.01 \mathrm{M}$ sodium phosphate, $\mathrm{pH} 7.0$, and eluted in increasing $1.5 \mathrm{M} \mathrm{NaCl}$ gradient (Buffer $\mathrm{B}, 0-100 \%$ ) with the same buffer at a flow rate of $2.5 \mathrm{~mL} / \mathrm{min}$. Fractions of $3 \mathrm{~mL}$ were collected and analyzed in a spectrophotometer $\left(\lambda_{280} \mathrm{~nm}\right)$. (B) SDS-PAGE using a $13 \%$ acrylamide-bisacrylamide $(\mathrm{w} / \mathrm{v})$ gel in Tris-glycine buffer, $\mathrm{pH}$ 8.3. Lane 1: molecular weight markers. Lane 2: crude venom $(\mathrm{CV})(10 \mu \mathrm{g})$ and Lane 3 : Crotamine $(10 \mu \mathrm{g})$ the ADP positive control ( $85 \%)$. The crude venom at the two concentrations analyzed ( 1.4 and $0.1 \mu \mathrm{g} / \mu \mathrm{L})$ under the same conditions demonstrated a similar effect to isolated native crotamine (Fig. 5).

\subsection{Effects of crotamine on mitochondrial function}

Crotamine, a cell-penetrating peptide, has been reported in the literature as causing mitochondrial and sarcoplasmic reticulum swelling (Fletcher et al., 1996; Nascimento et al., 2012). However, the mechanisms of this effect are unknown. Several toxins can interfere on and modify physiological mechanisms, and in many cases the preferential target is mitochondria (Bragadin, 2006). Therefore, to confirm the hypothesis that crotamine interacts with this organelle, we assessed mitochondrial oxidative phosphorylation. The results showed that crotamine was able to affect mitochondrial respiration when it is energized with succinate, a substrate for complex II of the mitochondrial respiratory chain. The respiratory control ratio (RCR) revealed decreased oxygen consumption at all crotamine concentrations (Fig. 6A). However, the ADP consumption by oxygen molecule (ADP/O) was not diminished in the groups treated with crotamine (Fig. 6B). In contrast, the velocity values in state IV (V4) had a considerable increase, demonstrating the ability of the peptide to act as an uncoupler agent of the mitochondria (Fig. 6C).

Mitochondrial swelling triggers the release of proteins located in the matrix or in the intermembrane space of mitochondria exposed to xenobiotics (Rasola and Bernardi, 2007a; b; Halestrap, 2009). The evaluation of mitochondrial swelling demonstrated the ability of crotamine to modify the permeability of the mitochondrial membrane and consequently its integrity and selectivity. This effect was expected because the tested peptide has cellpenetrating ability. Fig. 7A shows statistically significant differences $\left({ }^{*} p<0.05\right)$ between the treated and the control group (without addition of crotamine). The compound (Fig. 7B) exerted an effect at the three highest concentrations $(100,500$ and $1000 \mu \mathrm{g} /$ $\mathrm{mL}$ ), but only at $1000 \mu \mathrm{g} / \mathrm{mL}$ the effect was significant. As shown in Fig. 7C, pre-incubation of mitochondria with mitochondrial swelling modulators prior to exposure to crotamine partially inhibited this effect. The swelling was prevented in the presence of $1 \mu \mathrm{M}$ CsA, $0.5 \mu \mathrm{M}$ and $25 \mu \mathrm{M}$ ruthenium red, $25 \mu \mathrm{M}$ N-ethylmaleimide and also by $25 \mu \mathrm{M}$ butylated hydroxytoluene.

The ability of crotamine to alter the mitochondrial redox state was determined by the levels of TBARS and by monitoring the oxidation of sulfhydryl groups.

Our results demonstrate that crotamine in the concentrations used did not cause lipoperoxidation in the mitochondria compared to the positive control $\left(\mathrm{H}_{2} \mathrm{O}_{2}\right)$, as shown in Fig. 8A. This data corroborates the fact that crotamine did not induce the oxidation of sulfhydryl groups present in the mitochondrial membrane (Fig. 8B).

\section{Discussion}

In this study, we isolated crotamine, a cell penetrating peptide (CCP) from Crotalus durissus terrificus venom. Crotamine was purified by a new method, in a single step chromatography, using Heparin Sepharose column. Heparin Sepharose matrix is a highly sulphated glycosaminoglycan with the ability to bind a very wide range of biomolecules, such as DNA binding proteins, serine protease inhibitors, proteases, coagulation enzymes, and growth factors (Kan et al., 1993; Farooqui et al., 1994). Due to its unique structure and surface charge distribution, heparin is able to interact strongly with many enzymes and macromolecules in two ways: a positive, cooperative binding, and a specific binding. According to Nascimento et al. (2007) the mechanism of crotamine penetration 

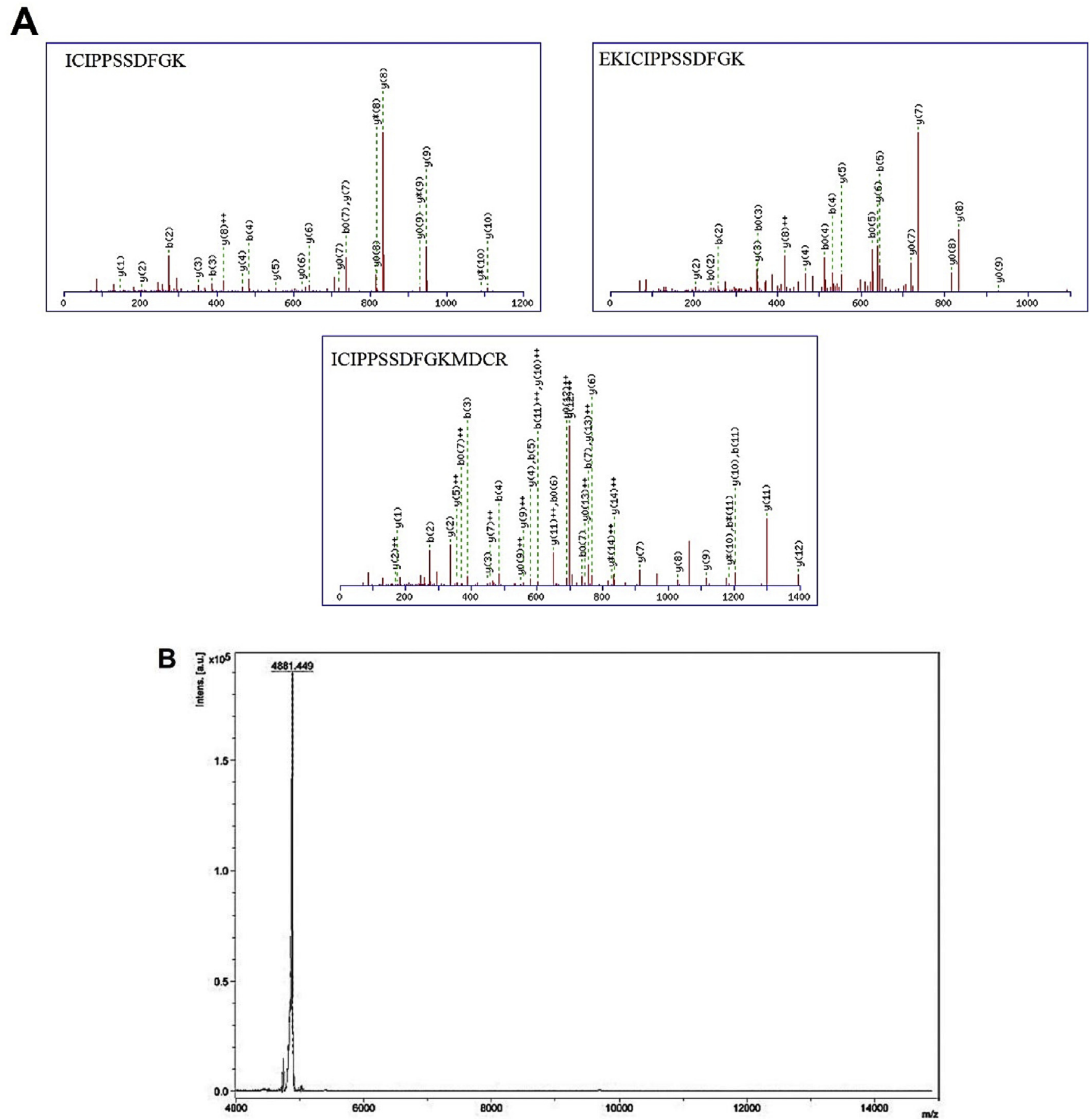

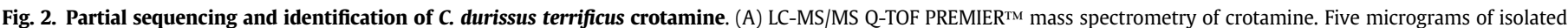

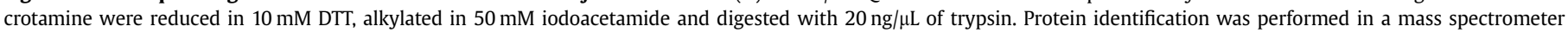

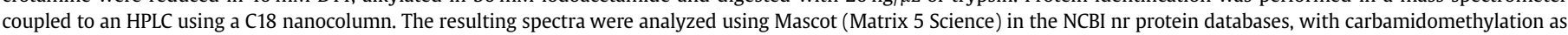

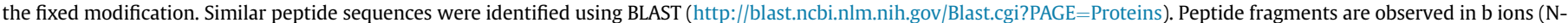

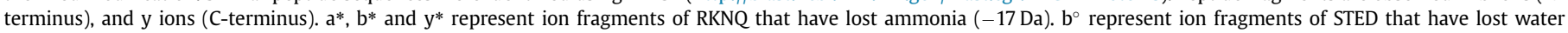

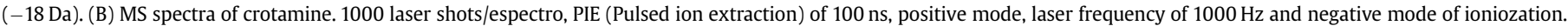
Voltage of $20 \mathrm{kV}$ (IS1) and $18.05 \mathrm{kV}$ (IS2). Reflector voltage of $21.3 \mathrm{kV}$ (RV1) and $10.7 \mathrm{kV}$ (RV2). For calibration and equipment, Bruker peptides were used.

and cargo delivery into cells involves heparan sulfate proteoglycans interaction in the uptake phase and high cell nuclear affinity. Thus, the present method of isolation the crotamine was used considering these two mechanisms. The degree of purity of crotamine was confirmed by matrix-assisted laser desorption/ionization (MALDITOF/TOF) spectrometry that presented a good resolution peak.
Purification process of crotamine was conducted under neutral conditions in order to confer greater stability during the isolation of the molecule, since previous studies have shown that crotamine may exhibit variable structural conformation depending on $\mathrm{pH}$ (Beltran et al., 1985). In addition, several studies on the isolation and biochemical characterization of crotamine have used two or 
A
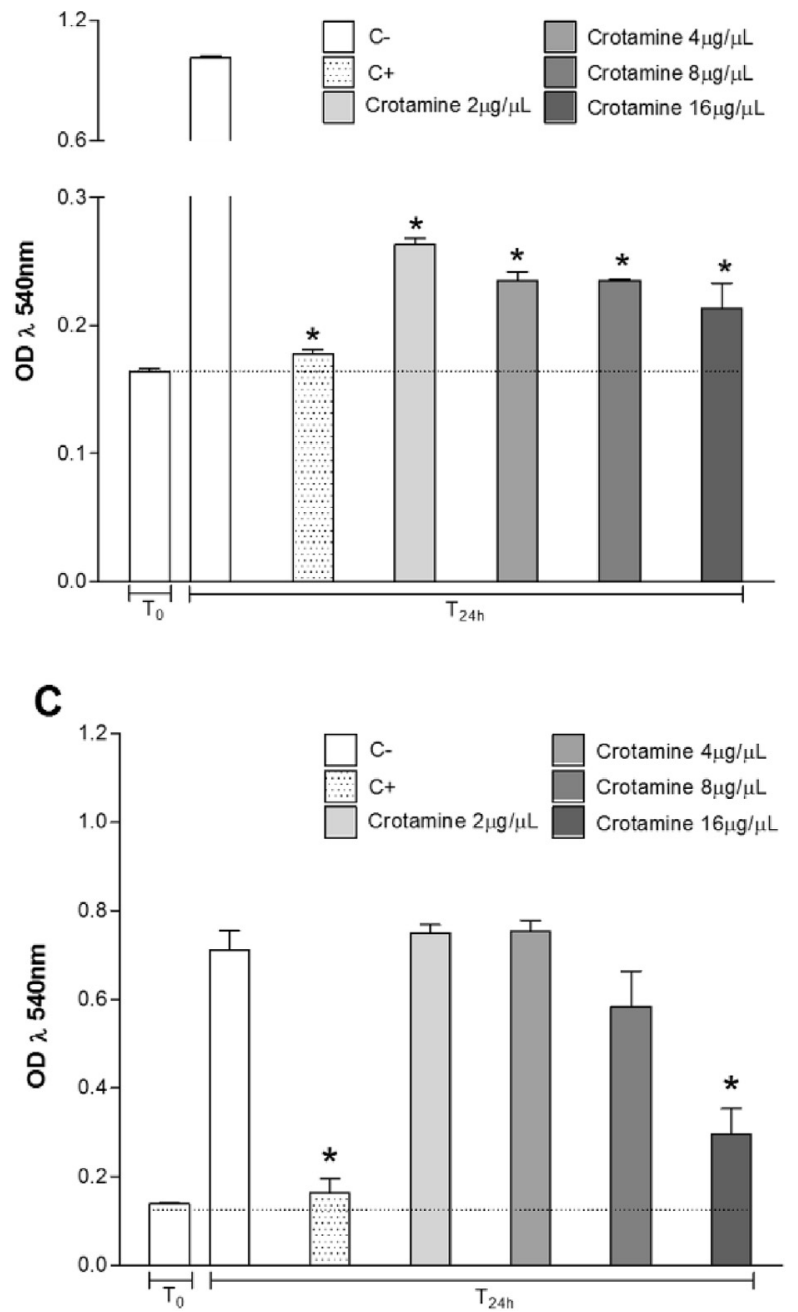

B

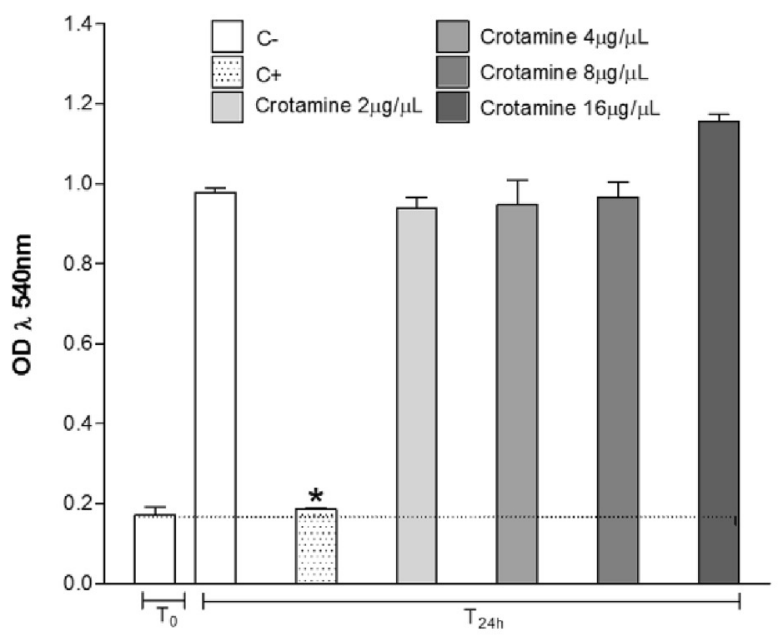

D

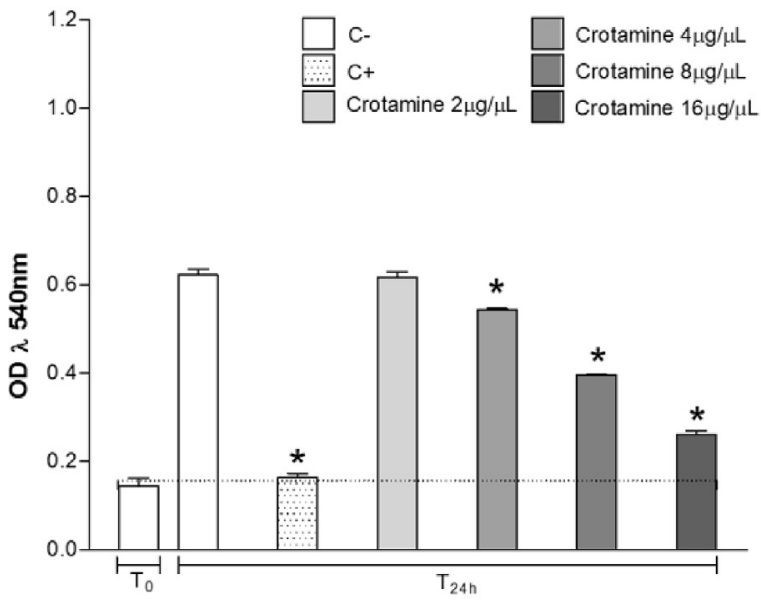

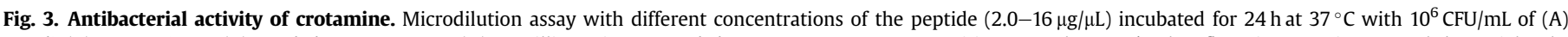

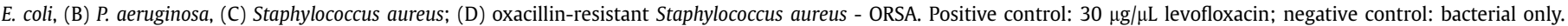
Values are reported as mean \pm SD (Student's t-test, ${ }^{*} \mathrm{p}<0.05$ relative to the positive control, $\mathrm{n}=3$ ).

more chromatographic steps including classical molecular exclusion associated with ion exchange (Hampe et al., 1990; Mancin et al., 1998; Boni-Mitake et al., 2001). Here, the bioaffinity-based method was selective, reproducible, and fast.

The identity of crotamine was confirmed by mass spectrometric analysis. Three internal peptide fragments (ICIPPSSDFGK; ICIPPSSDFGKMDCR and EKICIPPSSDFGK) were generated by mass fingerprinting. We identified that the first residue of the mature form of the protein was Ile. Databank analyses show that crotamine has proline and leucine/isoleucine amino acids highly conserved in the peptide. The identity of crotamine was experimentally confirmed, showing a $98 \%$ similarity. The analysis by MALDI-TOF/ TOF spectrometry showed a molecular mass of $4881.449 \mathrm{Da}$, which agrees with the theoretical mass of the peptide (4885.6 Da) (Peigneur et al., 2012). Previous studies report that geographical factors, the age of the snake and intra-species genetic variations may alter the chemical composition of the venom as well as the expression of crotamine, characterizing crotamine-positive and crotamine-negative snake species (Teno et al., 1990; Francischetti et al., 2000; Saravia et al., 2002; Nicastro et al., 2003; RádisBaptista et al., 2003; Rádis-Bastista et al., 2004; Fadel et al., 2005). Rádis-Baptista et al. (1999) also report the presence of crotamine isoforms, revealing a single base change of the amino acid leucine replaced by isoleucine at position 19. Moreover, Toyama et al. (2000) showed by high performance liquid chromatography the existence of crotamine isoforms with very close molecular weights of $4882.03 \mathrm{Da}$ and 4882.16 Da.

Currently, there is a great interest in the research and discovery of new antimicrobial drugs due to the high incidence of infectious diseases and the existence of microorganisms multiresistant to the conventional antibiotics (Roca et al., 2015). Among the highest priority microorganisms for public health are Acinetobacter, Pseudomonas, Klebsiella, E. coli, Serratia and Proteus, and other species that have acquired resistance such as Staphylococcus aureus, Helicobacter pylori, Salmonella spp, Neisseria gonorrhoeae, Shigella spp., and Streptococcus pneumoniae (WHO, 2017). Several studies have shown the antimicrobial action of crotamine on different microorganisms, including bacteria, yeasts and parasites. In these studies, the cytotoxic profile of the molecule was shown to be variable, with MICs ranging from 1 to $100 \mu \mathrm{g} / \mathrm{mL}$, depending on the microorganism (Passero et al., 2007; El-Chamy-Maluf et al., 2016).

In the present study, different concentrations of crotamine $(2-64 \mu \mathrm{g} / \mu \mathrm{L})$ were used to determine and confirm the MICs on different strains of clinical interest, such as Escherichia coli (ATCC 

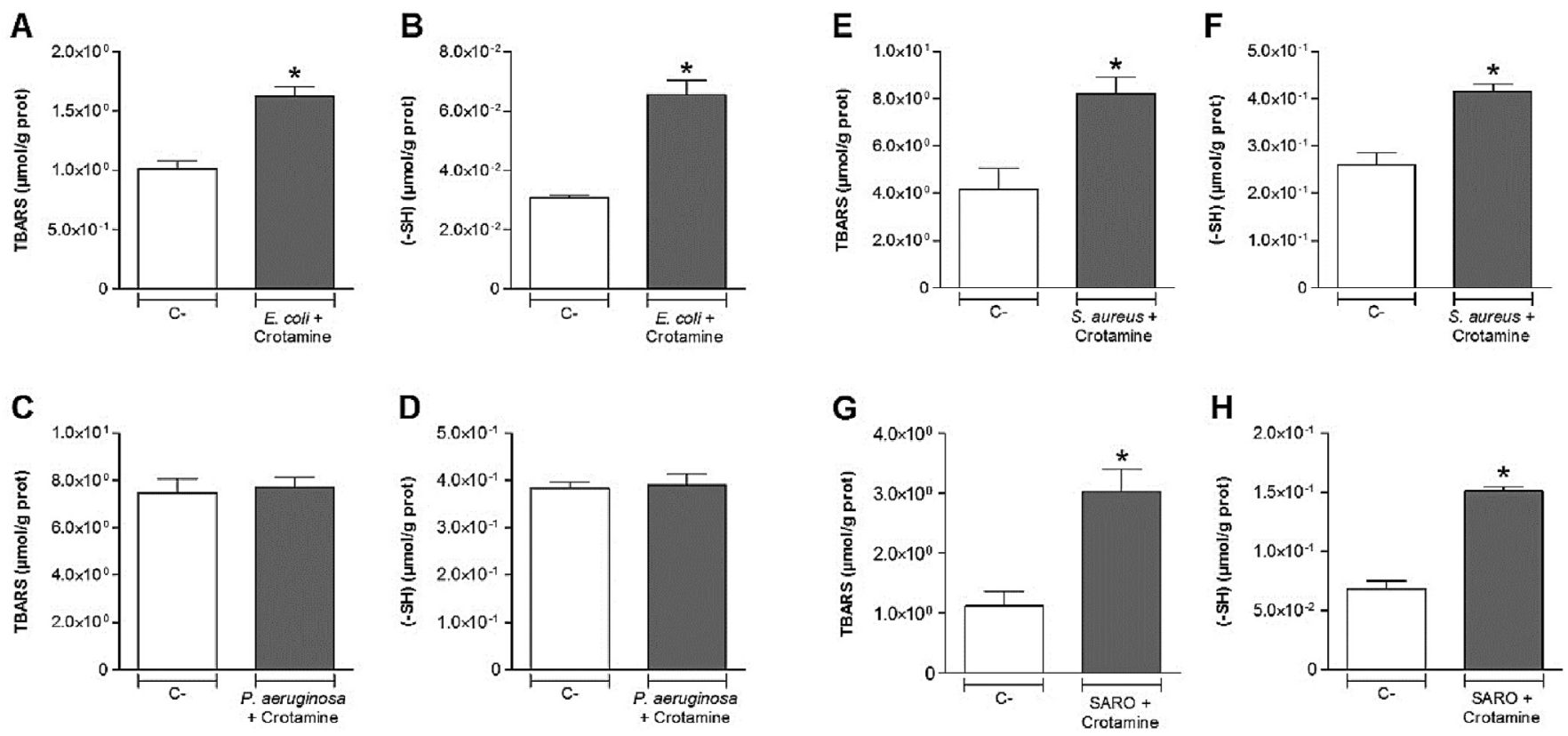

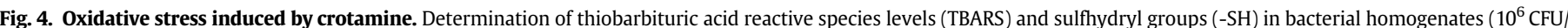

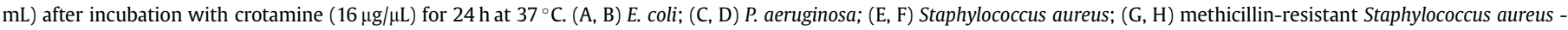
MRSA. Negative control: bacteria only. Values are reported as mean \pm SD (Student's t-test, ${ }^{*} \mathrm{p}<0.05$ compared to the positive control, $\mathrm{n}=3$ ).

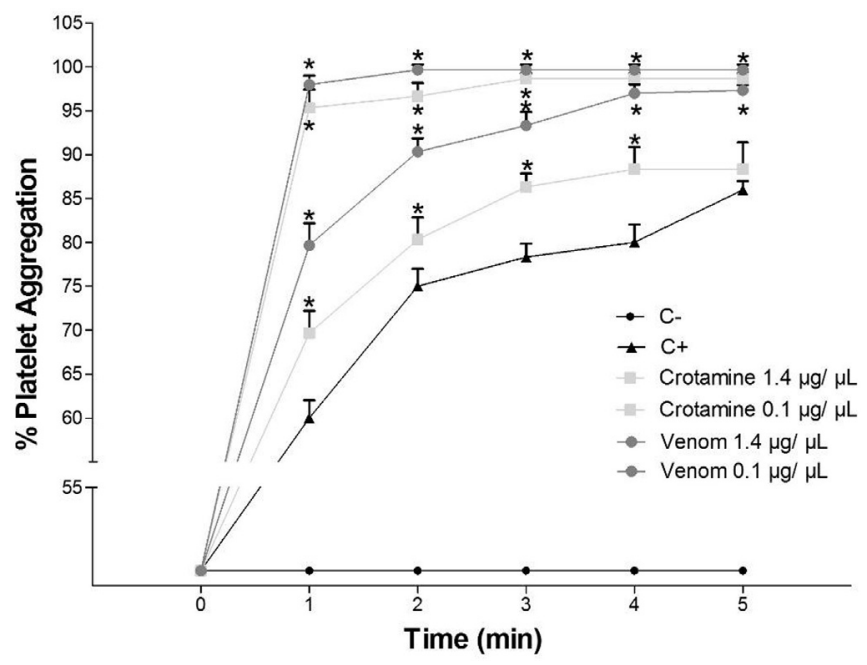

Fig. 5. Platelet aggregation induced by crotamine. Human platelet aggregation was induced by crotamine from the venom of Crotalus durissus terrificus. Different concentrations of the purified peptide and crude venom $(0.1$ and $1.4 \mu \mathrm{g} / \mu \mathrm{L})$ were immediately added to PRP and the reaction was monitored in Chrono-Log Model 700 Whole Blood/Optical Lumi-Aggregometer $\left(\lambda_{935-955 \mathrm{~nm}}, 5 \mathrm{~min}, 37^{\circ} \mathrm{C}\right)$. Reading was transcribed by Aggro/Link software 8. Data represent the average of three experiments $+\mathrm{SD}$. Results are reported as percentage of aggregation. $C_{+}$: positive control (ADP $1 \mathrm{nM} / \mu \mathrm{L}$ ); C: negative control (PRP $5 \times 10^{5}$ platelets $/ \mathrm{mL}$ ) (Student $t$-test, ${ }^{*} p<0.05$ compared to the positive control, $n=3$ ).

25922), Pseudomonas aeruginosa (ATCC 27853), Staphylococcus aureus (ATCC 25923) and methicillin-resistant Staphylococcus aureus (MRSA) (ATCC 33591). A heterogeneous response pattern was verified according to the sensitivity profile for each microorganism.

The cytotoxic potential of crotamine was better evidenced on E. coli compared to the positive control (microorganisms alone), and growth inhibition occurred at the lowest concentration $(2.0 \mu \mathrm{g} /$ $\mu \mathrm{L})$. However, studies performed by Oguiura et al. (2011) demonstrated that $S$. aureus species was more resistant to crotamine at up to $0.2 \mu \mathrm{g} / \mu \mathrm{L}$ concentrations than the $E$. coli species $(0.025-0.1 \mu \mathrm{g} / \mu \mathrm{L})$. Yamane et al. (2013) also found high antimicrobial activity of crotamine against $E$. coli and S. aureus with MICs of $0.05-0.2 \mu \mathrm{g} / \mu \mathrm{L}$. In contrast, we found that E. coli, S. aureus and MRSA presented higher sensitivity using concentrations of 2, 4 and $8 \mu \mathrm{g} / \mu \mathrm{L}$, respectively. However, $P$. aeruginosa was not sensitive to the peptide, even with the highest concentration.

To better understand the bactericidal activity of crotamine, our study assessed the oxidative stress caused by crotamine as a possible mechanism of action against the evaluated species. The minimum inhibitory concentration of the peptide ( $\mathrm{MIC}=16 \mu \mathrm{g} / \mu \mathrm{L}$ ) produced an increase in TBARS, which suggests oxidative events on membrane lipids. Accordingly, the levels of sulfhydryl groups (-SH), resulting from an attempt to combat oxidative attack were also elevated. These results imply that crotamine induces changes in the redox state, with the generation of toxic products and byproducts that may affect membrane fluidity as well as the formation of adducts between proteins and DNA, affecting cell metabolism and growth (Hanne et al., 2000; Medeiros, 2009). In contrast, the oxidative events resulting from crotamine treatment evidenced in E. coli, S. aureus and ORSA were not observed in P. aeruginosa, which presented low levels of TBARS and sulfhydryl groups. These results suggest that $P$. aeruginosa was not sensitive to crotamine and thus did not experience enough oxidative damage to interfere with its metabolism. Recent studies have shown that the OhrA-peroxidase gene and its OhrR negative regulator are the main genes responsible for detection and detoxification of organic hydroperoxides (Lesniak et al., 2003; Atichartpongkul et al., 2010). In addition, $P$. aeruginosa has been shown to have multiple mechanisms of resistance to antibacterial drugs, many of which are related to target site modifications, overexpression of efflux pumps (MexABOprM, MexCD-OprJ, MexEF-OprN and MexXY-OprM), and enzymatic hydrolysis by $\beta$-lactamases and metallo- $\beta$-lactamases. Moreover, drug resistance of $P$. aeruginosa is related with the low expression, if any, of porins such as OprC, OprD, OprE and OprF, and the expression of blocking porins, such as OprH (Young et al., 1992; 
A

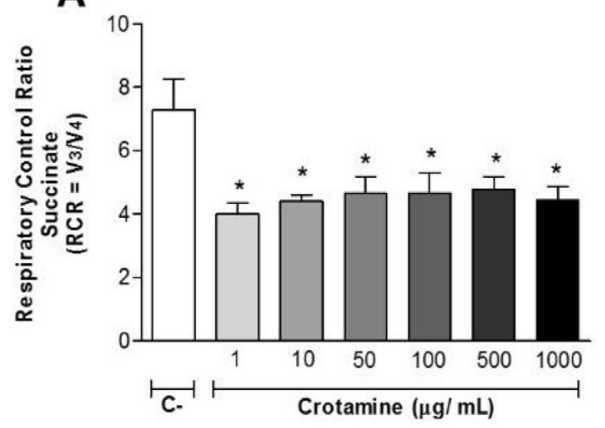

B

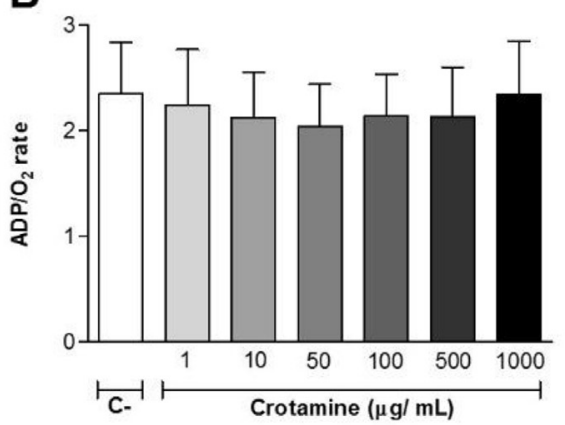

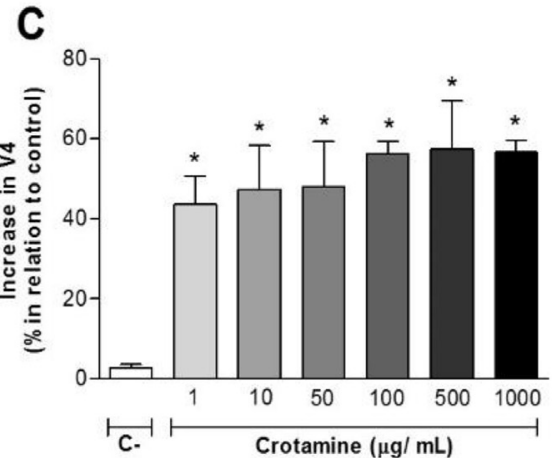

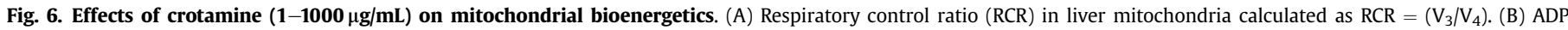

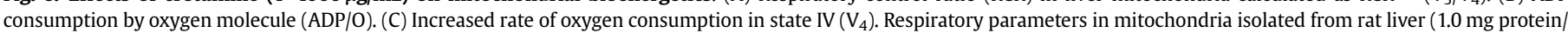

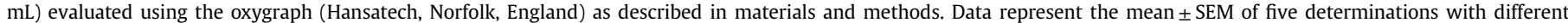
mitochondrial preparations $(n=5)$. *Statistically significant results $(p<0.05)$ compared with the control (absence of crotamine).

A
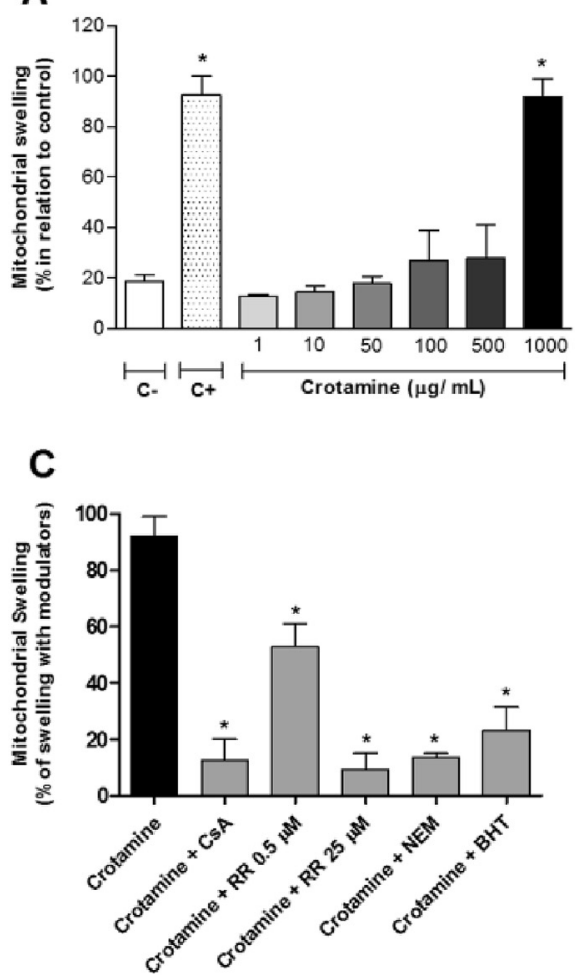

B

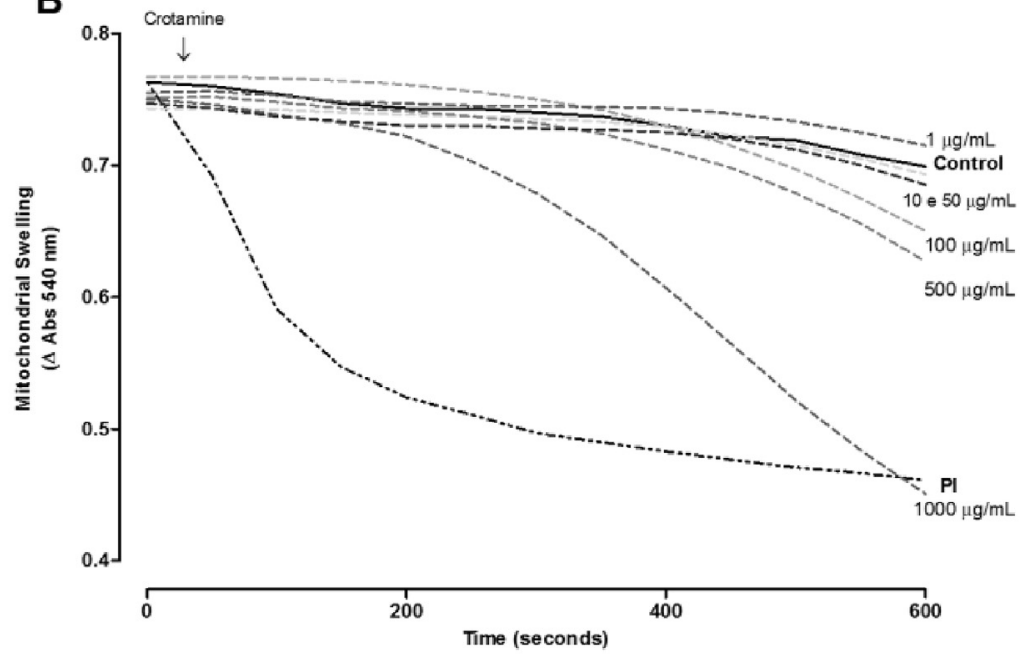

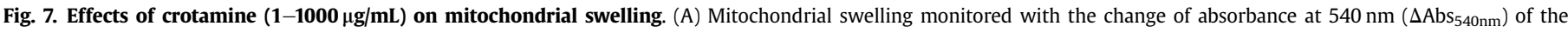

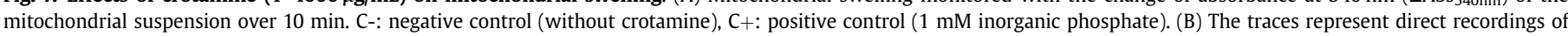

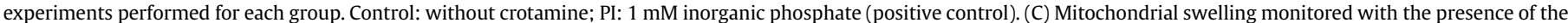

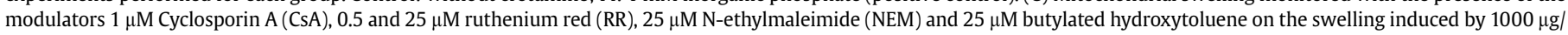

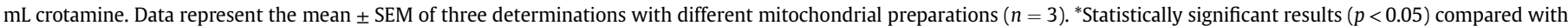
the control.

Khan et al., 1995; Livermore, 2002; Strateva and Yordanov, 2009).

Based on different in vitro assays and studies on the structurefunction of crotamine suggest that its bactericidal mechanism occur due to its amphipathic structure (Oguiura et al., 2011; Yamane et al., 2013; Costa et al., 2014). Crotamine presents a high positive net charge on the surface, which facilitates its binding to negatively charged surfaces driven by electrostatic interaction, as observed for other antimicrobial cationic peptides. Another hypothesis is that crotamine may induce the formation of gaps, through which ions and/or other molecules can diffuse on the outer bacterial, leading to consequent cell death (Coronado et al., 2013; Costa et al., 2014). This mechanism was observed in the studies by Oguiura et al. (2011), in which crotamine was effective against different strains of Escherichia coli (E. coli ATTC 25922; E. coli O157: H7; E. coli ML-35p), with lysis evidenced by the release of cell contents. The interaction of crotamine with cell membranes was also verified with Candida spp., which presented ultra-membrane alterations accompanied by loss of cellular integrity, assessed by electron microscopy (Yamane et al., 2013).

Studies using previously isolated fractions of the venom have 

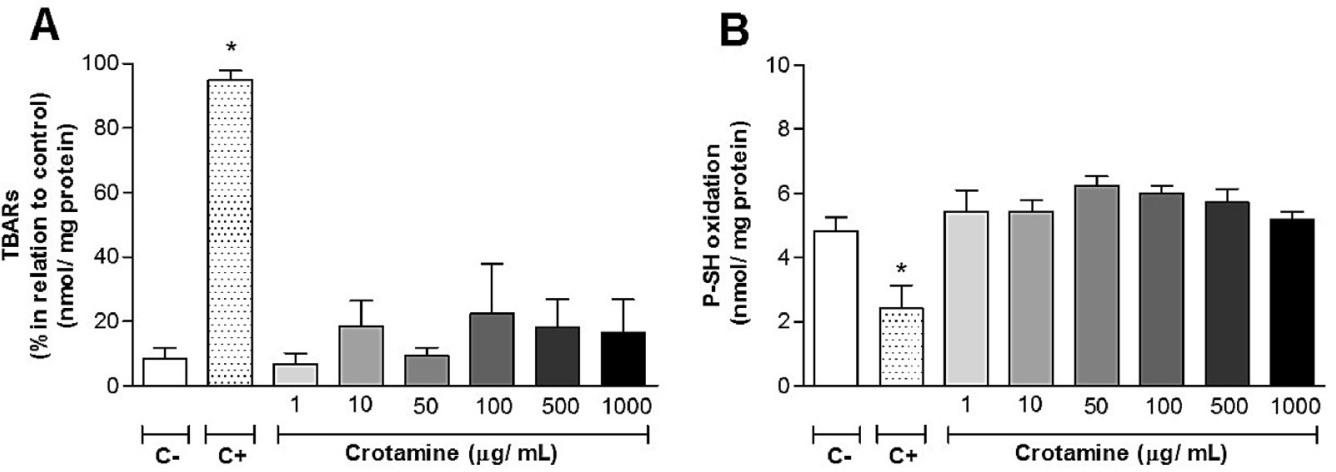

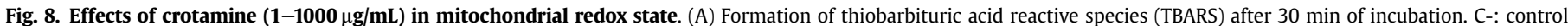

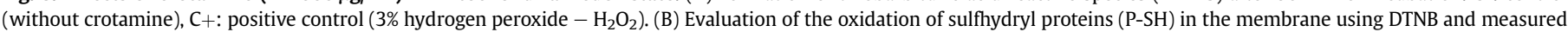

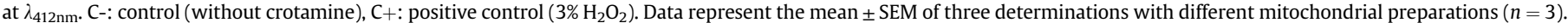
*Statistically significant results $(p<0.05)$ compared with the control.

shown a marked pro-coagulant activity for crotoxin (Fonseca et al., 2006) and gyroxine (a "thrombin-like" enzyme) (Magalhães et al., 2007; Yonamine et al., 2009), in addition to selective activation and inactivation of coagulation factors involved in platelet aggregation, coagulation and fibrinolysis (Serrano and Maroun, 2005). On the other hand, there are no reports on the effect of crotamine on platelet aggregation, as well as on mechanisms involved in this process. In our study, the effect of two different concentrations of crotamine on platelet-rich plasma was analyzed. Interestingly, platelet aggregation was induced by approximately $90 \%$ with the lowest concentration of the peptide $(0.1 \mu \mathrm{g} / \mu \mathrm{L})$ and by $99 \%$ with highest concentration $(1.4 \mu \mathrm{g} / \mu \mathrm{L})$ when compared to the ADPcontrol (85\% aggregation). It is suggested, therefore, that crotamine acts on different platelet targets, including glycoprotein receptors, called integrins (Rivera et al., 2009; Cupit et al., 2004). These data are of great relevance in possible future applications of this molecule in the study of platelet receptors and dysfunctions.

In the literature, crotamine is described as having high tropism for kidneys, muscles and liver (Boni-Mitake et al., 2006). According to Jaeschke et al. (2002), the liver is an important target for the harmful effects of chemical substances in general, mainly due to its function in metabolism. Here, we show for the first time the interaction of crotamine on hepatic mitochondria. The tests were performed with the objective to elucidate the mechanisms of action of crotamine and its interactions with biological systems. So far, many toxins have been studied for their effects in this organelle; for example, the uncoupling of oxidative phosphorylation by juliprosopine on rat brain mitochondria (Maioli et al., 2012), the oxygen consumption and electrical membrane potential by veratrine and veratridine in isolated rat skeletal muscle and liver mitochondria (Freitas et al., 2006) and cyclosporine A-insensitive mitochondrial permeability transition induced by dehydromonocrotaline (dos Santos et al., 2009).

Mitochondrial dysfunction is a relevant mechanism for mammals, particularly in the liver, since this organelle has a central and decisive function in cellular homeostasis (Amacher, 2005). To evaluate the potential involvement of mitochondria in the interaction of crotamine with biological systems, we addressed its effects primarily in oxidative phosphorylation. Thus, we may say that the mitochondria, particularly the mitochondrial respiratory chain, are a target of crotamine, as we observed a decrease in oxygen consumption and parallel increase in the state IV rate, which indicates that the peptide has the capacity to act as an uncoupling agent. Some compounds, classified as uncouplers, increase the conductance of the protons by the internal mitochondrial membrane (Wallace and Starkov, 2000), which can trigger the mitochondrial swelling process. This phenomenon, known as mitochondrial swelling, comprises a series of steps that can induce the mitochondrial membrane permeability transition (MPT), defined as a sudden increase in the permeability of the internal mitochondrial membrane to solutes with molecular masses of up to $1500 \mathrm{kDa}$, due to the opening of a high-conductance cyclosporine-A and $\mathrm{Ca}^{+2}$-dependent channels (Rasola, Bernardi, 2007a; b; Tsujimoto and Shimizu, 2007).

The interference caused by crotamine in mitochondria bioenergetic process might be responsible for the changes in mitochondrial permeability. It is also possible that a mechanisms of action of crotamine is the opening of the mitochondrial permeability pore, since the observed swelling was inhibited significantly by cyclosporine, a classic inhibitor of MPT (Broekemeier et al., 1989). In line with these findings, the observed swelling is also calcium-dependent, since it was sensitive to ruthenium red, which gives us an indication that the $\mathrm{Ca}^{+2}$ ion is also an important agent of MPT induced by this compound. It was also observed that NEM and BHT partially reduce mitochondrial swelling. However, no change was detected in the mitochondrial redox state. This suggests that the compound did not cause mitochondrial oxidative stress, but it is possible that crotamine is able to interact with the $\mathrm{SH}$ proteins of mitochondrial membranes, since stabilizing them with NEM prevented swelling. In a study using melanoma cell lines (B16F10) Nascimento et al. (2012) showed that the cytotoxic effect of crotamine involves rapid intracellular calcium release and loss of mitochondrial membrane potential and, consequently induction of apoptosis via caspases activation. Valente et al. (1998) studied the effect of three purified phospholipase $A_{2}$ isoforms isolated from C. d. terrificus on mitochondria and showed that PLA 2 isoforms cause a dose-dependent swelling and $\mathrm{O}_{2}$ consumption through an enzymatic mechanism.

Mitochondria performance depended on a proton electrochemical gradient generated by respiration and maintained by the impermeability of the inner mitochondrial membrane to protons (Kehrer and Lund, 1994; Pessayre et al., 1999). It has been well documented that the decrease of ATP levels is one of the consequences of mitochondrial damage and a critical event that leads to cell death by necrosis or apoptosis (Nicotera et al., 1998; Wallace and Starkov, 2000; Szewczyk and Wojtczak, 2002). Consistent with the possibility of cell death by the effects observed in mitochondria after exposure to crotamine, it is noteworthy that in the inner mitochondrial membrane have the presence of Kv1.3, a shaker potassium channel family of the, functionally active in the 
mitochondrial inner membrane - mitoKv1.3 (Szabò et al., 2008), and such as previously described this channel is target of crotamine. Therefore, the interaction of crotamine with the mitochondria can become an important ally when cell death is desired.

\section{Conclusions}

In conclusion, native crotamine from Crotalus durissus terrificus was purified with homogeneity. The purified peptide showed remarkable pro-aggregating activity on platelets. Interestingly, the molecule effect on bacteria seems to be through oxidative stress. Mechanistically, the mitochondrial respiratory chain is a target of crotamine, which indicates that the peptide has the capacity to act as an uncoupling agent in association with the opening of the mitochondrial membrane permeability pore. Thus, the activities found in this fraction of the venom can contribute to the understanding of the structure-activity relationship of these biomolecules, as well as the physiological and molecular mechanisms in different biological models. Thus this study contributes to the future use of crotamine in the development of biotechnology products with clinical application.

\section{Conflicts of interest}

The authors declare that they have no conflicts of interest.

\section{Ethical statement}

The experiments followed the methodology recommended by the international ethical standards of the scientific committee of our university (process $n^{\circ} 833 / 2015$ and 014/2017).

\section{Acknowledgments}

The current study was supported by grants from FAPESP and the Hermínio Ometto University Center. We acknowledge the Mass Spectrometry Laboratory of the Brazilian Biosciences National Laboratory, CNPEM, Campinas, Brazil, for providing support for the mass spectrometry analysis. We also acknowledge the Blood Hemostasis Laboratory, Faculty of Medical Sciences (UNICAMP).

\section{Transparency document}

Transparency document related to this article can be found online at https://doi.org/10.1016/j.toxicon.2018.03.007.

\section{Appendix A. Supplementary data}

Supplementary data related to this article can be found at https://doi.org/10.1016/j.toxicon.2018.03.007.

\section{References}

Amacher, D.E., 2005. Drug-associated mitochondrial toxicity and its detection. Curr. Med. Chem. 12 (16), 1829-1839. https://doi.org/10.2174/0929867054546663.

Atichartpongkul, S., Mayuree, F., Vattanaviboon, P., Mongkolsuk, S., 2010. Analyses of the regulatory mechanism and physiological roles of Pseudomonas aeruginosa OhrR, a transcription regulator and a sensor of organic hydroperoxides. J. Of Bacteriol. 192 (8), 2093-2101. https://doi.org/10.1128/JB.01510-09.

Beltran, J.R., Mascarenhas, Y.P., Craievich, A.F., Laure, C.J., 1985. Saxs study of structure and conformational changes of crotamine. Biophys. J. 47 (1), 33-35. https://doi.org/10.1016/S0006-3495(85)83873-X.

Bercovici, D., Chudzinski, A.M., Dias, W.O., Esteves, M.I., Hiraichi, E., Olshi, N.Y., Picarelli, Z.P., Rocha, M.C., Ueda, C.M.P.M., Yamanouye, N., Raw, I., 1987. A systematic fractionation of Crotalus durissus terrificus. Venom. Mem. Inst. Butantan 49 (3), 69-78.

Bjarnason, J.B., Fox, J.W., 1994. Hemorrhagic metalloproteinases from snake venons. Pharmacol. Ther. 62 (3), 325-372.
Boni-Mitake, M., Costa, H., Spencer, P.J., Vassilieff, V.S., Rogero, J.R., 2001. Effects of ${ }^{60}$ Co gamma radiation on crotamine. Braz. J. Med. Biol. 34 (12), 1531-1538. https://doi.org/10.1590/S0100-879X2001001200004.

Boni-Mitake, M., Costa, H., Vassilieff, V.S., Rogero, J.R., 2006. Distribution of (125)Ilabeled crotamine in mice tissues. Toxicon 48 (5), 550-555. https://doi.org/ 10.1016/j.toxicon.2006.07.005.

Bragadin, M., 2006. The mitochondria: ATP synthesis and its inhibition by toxic compounds. In: Moreno, A.J.M. (Ed.), Mitochondrial Pharmacology and Toxicology. Transworld Research Network, Kerala, India, pp. 1-22.

Broekemeier, K.M., Dempsey, M.E., Pfeiffer, D.R., 1989. Cyclosporin A is a potent inhibitor of the inner membrane permeability transition in liver mitochondria. J. Biol. Chem. 264, 7826-7830.

Buege, J.A., Aust, S.D., 1978. Microsomal lipid peroxidation. Methods Enzymol. 52 302-310. https://doi.org/10.1016/S0076-6879(78)52032-6.

Cain, K., Skilleter, D.N., 1987. Preparation and use of mitochondria in toxicological research. In: Snell, K., Mullock, B. (Eds.), Biochemical Toxicology: a Practical Approach. IRL Press, Oxford, pp. 217-254.

Cameron, D.L., Tu, A.T., 1978. Chemical and functional homology of myotoxin a from prairie rattlesnake venom and crotamine from South American rattlesnake venom. Biochim. Biophys. Acta 532 (1), 147-154. https://doi.org/10.1016/00052795(78)90457-9.

Camillo, M.A., Arruda Paes, P.C., Troncone, L.R., Rogero, J.R., 2001. Gyroxin fails to modify in vitro release of labelled dopamine and actylcholine from rat and mouse striatal tissue. Toxicon 39 (6), 843-853. https://doi.org/10.1016/S00410101(00)00222-1.

Chance, B., Willians, G.R., 1956. The respiratory chain and oxidative phosphorylation. Adv. Enzymol. Relat. Subj. Biochem. 17, 65-134.

Chang, C.C., Tseng, K.H., 1978. Effect of crotamine, a toxin of South American rattlesnake venom, on the sodium channel of murine skeletal muscle. Br. J Pharmacol. 63 (3), 551-559. https://doi.org/10.1111/j.1476-5381.1978.tb07811.x.

Cheymol, J., Gonçalves, J.M., Bourillet, F., Roch-Arveiller, M., 1971. A comparison of the neuromuscular action of crotamine and the venom of Crotalus durissus terrificus var. crotaminicus. Neuromuscular preparations in situ. Toxicon 9 (3) 279-286. https://doi.org/10.1016/0041-0101(71)90081-X.

Coronado, M.A., Gabdulkhakov, A., Georgieva, D., et al., 2013. Structure of the polypeptide crotamine from the Brazilian rattlesnake Crotalus durissus terrificus. Acta Crystallogr. Sect. D. Biol. Crystallogr. 69 (10), 1958-1964. https://doi.org/ 10.1107/s0907444913018003.

Costa, B.A., Sanches, L., Gomide, A.B., 2014. Interaction of the rattlesnake toxin crotamine with Model membranes. J. Of Phys. Chem. B 118 (20), 5471-5479. https://doi.org/10.1021/jp411886u.

Cupit, L.D., Schmidt, V.A., Gnatenko, D.V., Bahou, W.F., 2004. Expression of protease activated receptor 3 (PAR3) is upregulated by induction of megakaryocyte phenotype in human erythroleukemia (HEL) cells. Exp. Hematol. 32 (10), 991-999. https://doi.org/10.1016/j.exphem.2004.07.005.

Devienne, K.F., Cálgaro-Helena, A., Dorta, D.J., Prado, I.M.R., Raddi, M.S.G. Vilegas, W., Uyemura, S.A., Santos, A.C., Curti, C., 2007. Antioxidant activity of isocoumarins isolated from Paepalanthus bromelioides on mitochondria. Phytochemistry 68, 1075-1080. https://doi.org/10.1016/ j.phytochem.2007.01.014.

Dos Santos, A.B., Dorta, D.J., Pestana, C.R., Maioli, M.A., Curti, C., Mingatto, F.H., 2009. Dehydromonocrotaline induces cyclosporine A-insensitive mitochondrial permeability transition/cytochrome c release. Toxicon 54, 16-22. https:// doi.org/10.1016/j.toxicon.2009.03.004.

El-Chamy-Maluf, S., Dal Mas, C., Oliveira, E.B., Melo, P.M., Carmona, A.K. Gazarini, M.L., Hayashi, M.A., 2016. Inhibition of malaria parasite Plasmodium falciparum development by crotamine, a cell penetrating peptide from the snake venom. Peptides 78, 11-16. https://doi.org/10.1016 j.peptides.2016.01.013.

Esterbauer, H., Cheeseman, K.H., 1990. Determination of aldehydic lipid peroxidation products: malonaldehyde and 4-hydroxynonenal. Methods Enzymol. 186 407-421.

Fadel, V.B., Bettendorff, P., Herrmann, T., de Azevedo Jr., W.F., Oliveira, E.B., Yamane, T., Wüthrich, K., 2005. Automated NMR structure determination and disulfide bond identification of the myotoxin crotamine from. Crotalus durissus Terrificus. Toxicon. 46 (7), 759-767. https://doi.org/10.1016 j.toxicon.2005.07.018.

Farooqui, A.A., Yang, H.C., Horrocks, L.A., 1994. Purification of lipases, phospholipases and kinases by heparin-Sepharose chromatography. J. Of Chromatogr. A 673 (2), 149-158. https://doi.org/10.1016/0021-9673(94)85033-x.

Faure, P., lafond, J.L., 1995. Measurement of plasma sulphydryl and carbonyl groups as a possible indicator of protein oxidation. In: favier, A.E., et al. (Eds.), Analysis of Free Radicals in Biological Systems, pp. 237-248.

Fletcher, J.E., Hubert, M., Wieland, S.J., Gong, Q.H., Jiang, M.S., 1996. Similarities and differences in mechanisms of cardiotoxins, melittin and other myotoxins. Toxicon 34 (11), 1301-1311. https://doi.org/10.1016/S0041-0101(96)00105-5.

Fonseca, F.V., et al., 2006. Characterization of a new platelet aggregating factor from crotoxin Crotalus durissus cascavella venom. Protein J. 25 (3), 183-192. https:// doi.org/10.1007/s10930-006-9001-z.

Francischetti, I.M., Gombarovits, M.E., Valenzuela, J.G., Carlini, C.R., Guimarães, J.A., 2000. Intraspecific variation in the venoms of the South American rattlesnake (Crotalus durissus terrificus). Comp. Biochem. Physiol. C Toxicol. Pharmacol. 127 (1), 23-36. https://doi.org/10.1016/S0742-8413(00)00129-8.

Freitas, S.E.M., Fagian, M.M., Hofling, M.A.C., 2006. Effects of veratrine and veratridine on oxygen consumption and electrical membrane potential of isolated rat 
skeletal muscle and liver mitochondria. Toxicon 47, 780-787. https://doi.org/ 10.1016/j.toxicon.2006.02.009.

Gonçalves, J.M., Arantes, E.G., 1956. Studies on the venoms of Brazilian snakes. III. Quantitative determination of grotamine in the venom of Crotalus terrificus crotaminicus. An.Acad. Bras. Ciên. 28, 369-371.

Gutiérrez, J.M., Cerdas, L., 1984. Mechanism of action of myotoxins isolated from snake venoms. Rev. Biol. Trop. 32 (2), 213-222.

Halestrap, A.P., 2009. What is the mitochondrial permeability transition pore? J. Mol. Cell Cardiol. 46, 821-831. https://doi.org/10.1016/j.yjmcc.2009.02.021.

Hampe, O.G., Junqueira, N.O., Vozári-Hampe, M.M., 1990. Polyacrylamide gel electrophoretic studies on the self-association of crotamine: characterization and molecular dimension of n-mer species. Eletrophoresis 11 (6), 475-478. https:// doi.org/10.1002/elps.1150110607.

Hanne, H.F., Refsgaard, L.T., Stadtman, E.R., 2000. Modifications of proteins by polyunsaturated fatty acid peroxidation products. Proc. Natl. Acad. Sci. 97, 611-616. https://doi.org/10.1073/pnas.97.2.611.

Hayashi, M.A., Nascimento, F.D., Kerkis, A., Oliveira, V., Oliveira, E.B., Pereira, A., Rádis-Baptista, G., Nader, H.B., Yamane, T., Kerkis, I., Tersariol, I.L., 2008. Cytotoxic effects of crotamine are mediated through lysosomal membrane permeabilization. Toxicon 52 (3), 508-517. https://doi.org/10.1016 j.toxicon.2008.06.029.

Hayashi, M.A., Oliveira, E.B., Kerkis, I., Karpel, R.L., 2012. Crotamine: a novel cellpenetrating polypeptide nanocarrier with potential anti-cancer and biotechnological applications. Methods Mol. Biol. 906, 337-352. https://doi.org/ 10.1007/978-1-61779-953-2_28.

Jaeschke, H., Gores, G.J., Cederbaum, A.I., Hinson, J.A., Pessayre, D., Lemasters, J.J., 2002. Mechanisms of hepatotoxicity. Toxicol. Sci. 65, 166-176. https://doi.org $10.1093 /$ toxsci/65.2.166

Jocelyn, P.C., 1987. Spectrophotometric assay of thiols. Methods Enzymol. 143 44-67. https://doi.org/10.1016/0076-6879(87)43013-9.

Kan, M., Wang, F., Xu, J., et al., 1993. An essential heparin-binding domain in the fibroblast growth factor receptor kinase. Science 259 (5103), 1918-1921. https://doi.org/10.1126/science.8456318.

Kehrer, J.P., Lund, L.G., 1994. Cellular reducing equivalents and oxidative stress. Free Radic. Biol. Med. 17 (1), 65-75. DOI: 0891-5849(94)E0029-I.

Kerkis, A., Kerkis, I., Radis-Baptista, G., Oliveira, E.B., Vianna-Morgante, A.M. Pereira, L.V., Yamane, T., 2004. Crotamine is a novel cell-penetrating protein from the venom of rattlesnake Crotalus durissus terrificus. FASEB J. 18 1407-1409. https://doi.org/10.1096/fj.03-1459fje.

Kerkis, I., de Brandão Prieto da Silva, A.R., Pompeia, C., Tytgat, J., de Sá Junior, P.L., 2017. Toxin bioportides: exploring toxin biological activity and multifunctionality. Cell Mol. Life Sci. 74 (4), 647-661. https://doi.org/10.1007/s00018016-2343-6.

Khan, T.Z., et al., 1995. Early pulmonary inflammation in infants with cystic fibrosis. Am. J. Respir. Crit. Care Med. 151 (4), 1075-1082. https://doi.org/10.1164 ajrccm.151.4.7697234.

Koh, D.C., Armugam, A., et al., 2006. Snake venom components and their applications in biomedicine. Cell. Mol. Life Sci. 63 (24), 3030-3041. https://doi.org 10.1007/s00018-006-6315-0.

Lee, K.J., Kim, Y.K., Krupa, M., Nguyen, A.N., Do, B.H., Chung, B., Vu, T.T., Kim, S.C., Choe, H., 2016. Crotamine stimulates phagocytic activity by inducing nitric oxide and TNF- $\alpha$ via p38 and NFK-B signaling in RAW 264.7 macrophages. BMB Rep. 49 (3), 185-190. https://doi.org/10.5483/BMBRep.2016.49.3.271.

Lemasters, J.J., DiGuiseppi, J., Nieminen, A.L., Herman, B., 1987. Blebbing, free $\mathrm{Ca}^{2+}$ and mitochondrial membrane potential preceding cell death in hepatocytes. Nature 325 (6099), 78-81. https://doi.org/10.1038/325078a0.

Lesniak, J., Barton, W.A., Nikolov, D.B., 2003. Structural and functional features of the Escherichia coli hydroperoxide resistance protein OsmC. Protein Sci. 12, 2838-2843. https://doi.org/10.1110/ps.03375603.

Livermore, D.M., 2002. Multiple mechanisms of antimicrobial resistance in Pseudomonas aeruginosa: our worst nightmare? Clin. Infect. Dis. 34 (5), 634-640. https://doi.org/10.1086/338782.

Magalhães, A., Magalhães, H.P., Richardson, M., Gontijo, S., Ferreira, R.N Almeida, A.P., Sanchez, E.F., 2007. Purification and properties of a coagulant thrombin-like enzyme from the venom of Bothrops leucurus. Comp. Biochem. Physiol. A Mol. Integr. Physiol. 146 (4), 565-575. https://doi.org/10.1016/ j.cbpa.2005.12.033.

Maioli, M.A., Lemos, D.E.C.V., Guefi, M., Medeiros, H.C.D., Riet-Correa, F., Medeiros, R.M.T., Barbosa-Filho, J., Mingatto, F.H., 2012. Mechanism for the uncoupling of oxidative phosphorylation by juliprosopine on rat brain mitochondria. Toxicon 60, 1355-1362. https://doi.org/10.1016/j.toxicon.2012.09.012.

Mancin, A.C., Soares, A.M., Andriao-Escarso, S.H., Faca, V.M., Greene, L.J. Zuccolotto, S., Pela, I.R., Giglio, J.R., 1998. The analgesic activity of crotamine, neurotoxin from Crotalus durissus terrificus (South American rattlesnake) venom: a biochemical and pharmacological study. Toxicon Off. J. Int. Soc. Toxinology 36, 1927-1937. https://doi.org/10.1016/S0041-0101(98)00117-2.

Mancin, A.C., Soares, A.M., Giglio, C.A., Andrião-Escarso, S.H., Vieira, C.A., Giglio, J.R., 1997. The histamine releasers crotamine, protamine and compound 48/80 activate specific proteases and phospholipases A2. Biochem. Mol. Biol. Int. 42 (6), $1171-1177$.

Medeiros, M.H., 2009. Exocyclic DNA adducts as biomarkers of lipid oxidation and predictors of disease. Challenges in developing sensitive and specific methods for clinical studies. Chem. Res. Toxicol. 22, 419-425. https://doi.org/10.1021/ tx800367d.

Nascimento, F.D., Hayashi, M.A., Kerkis, A., Oliveira, V., Oliveira, E.B., Rádis-
Baptista, G., Nader, H.B., Yamane, T., Tersariol, I.L.S., Kerkis, I., 2007. Crotamine mediates gene delivery into cells through the binding to heparin sulfate proteoglycans. J. Biol. Chem. 282, 21349-21360. https://doi.org/10.1074/ jbc.M604876200.

Nascimento, F.D., Sancey, L., Pereira, A., Rome, C., Oliveira, V., Oliveira, E.B., Nader, H.B., Yamane, T., Kerkis, I., Tersariol, I.L., Coll, J.L., Hayashi, M.A., 2012. The natural cell-penetrating peptide crotamine targets tumor tissue in vivo and triggers a lethal calcium-dependent pathway in cultured cells. Mol. Pharm. 9 (2), 211-221. https://doi.org/10.1021/mp2000605.

Nicastro, G., Franzoni, L., De Chiara, C., Mancin, A.C., Giglio, J.R., Spisni, A., 2003. Solution structure of crotamine, a Na+ channel affecting toxin from Crotalus durissus terrificus venom. Eur. J. Biochem. 270 (9), 1969-1979. https://doi.org/ 10.1046/j.1432-1033.2003.03563.x.

Nicotera, P., Leist, M., Ferrando-May, E., 1998. Intracellular ATP, a switch in the decision between apoptosis and necrosis. Toxicol. Lett. 102-103, 139-142. https://doi.org/10.1016/S0378-4274(98)00298-7.

Oguiura, N., Boni-Mitake, M., Affonso, R., Zhang, G., 2011. In vitro antibacterial and hemolytic activities of crotamine, a small basic myotoxin from rattlesnake Crotalus durissus. J. Antibiot. 64 (4), 327-331. https://doi.org/10.1038/ ja.2011.10.

Ownby, C.L., Aird, S.D., Kaiser, I.I., 1988. Physiological and immunological properties of small myotoxins from the venom of the midget faded rattlesnake (Crotalus viridis concolor). Toxicon 26 (3), 319-323. https://doi.org/10.1016/00410101(88)90223-1.

Passero, L.F., Tomokane, T.Y., Corbett, C.E., Laurenti, M.D., Toyama, M.H., 2007. Comparative studies of the anti-leishmanial activity of three Crotalus durissus ssp. venoms. Parasitol. Res. 101 (5), 1365-1371. https://doi.org/10.1007/s00436007-0653-1.

Pedersen, P.L., Greenawalt, J.W., Reynafarje, B., Hullihen, J., Decker, G.L., Soper, J.W., Bustamente, E., 1978. Preparation and characterization of mitochondria and submitochondrial particles of rat liver and liver-derived tissues. Methods Cell Biol. 20, 411-481.

Peigneur, S., Orts, D.J., Prieto da Silva, A.R., Oguiura, N., Boni-Mitake, M., de Oliveira, E.B., Zaharenko, A.J., de Freitas, J.C., Tytgat, J., 2012. Crotamine pharmacology revisited: novel insights based on the inhibition of KV channels. Mol. Pharmacol. 82, 90-96. https://doi.org/10.1124/mol.112.078188.

Pereira, A., Kerkis, A., Hayashi, M.A., Pereira, A.S., Silva, F.S., Oliveira, E.B., Prieto da Silva, A.R., Yamane, T., Rádis-Baptista, G., Kerkis, I., 2011. Crotamine toxicity and efficacy in mouse models of melanoma. Expert Opin. Investig. Drugs 20 (9), 1189-1200. https://doi.org/10.1517/13543784.2011.602064.

Pessayre, D., Mansouri, A., Haouzi, D., Fromenty, B., 1999. Hepatotoxicity due to mitochondrial dysfunction. Cell. Biol. Toxicol. 15, 367-373. https://doi.org/ 10.1023/A:1007649815992.

Rádis-Baptista, G., et al., 1999. Nucleotide sequence of crotamine isoform precursors from a single South American rattlesnake (Crotalus durissus terrificus). Toxicon. 37 (7), 973-984. https://doi.org/10.1016/S0041-0101(98)00226-8.

Rádis-Baptista, G., et al., 2003. Structure and chromosomal localization of the gene for crotamine, a toxin from the South American rattlesnake, Crotalus durissus terrificus. Toxicon. 42 (7), 747-752. https://doi.org/10.1016/ j.toxicon.2003.10.019.

Rádis-Baptista, G., Kubo, T., Oguiura, N., Prieto da Silva, A.R., Hayashi, M.A., Oliveira, E.B., Yamane, T., 2004. Identification of crotasin, a crotamine-related gene of Crotalus durissus terrificus. Toxicon. 43 (7), 751-759. https://doi.org/ 10.1016/j.toxicon.2004.02.023.

Rasola, A., Bernardi, P., 2007a. The mitochondrial permeability transition pore and its involvement in cell death and in disease pathogenesis. Apoptosis 12, 815-833. https://doi.org/10.1007/s10495-007-0723-y.

Rasola, A., Bernardi, P., 2007b. The Mitochondrial Permeability Transition Pore and its Involvement in Cell Death and in Disease Pathogenesis. Apoptosis, Boston, pp. 815-833. https://doi.org/10.1007/s10495-007-0723-y, v. 12.

Rivera, J., Lozano, M.L., Navarro-Núnez, L., Vicente, V., 2009. Platelet receptors and signaling in the dynamics of thrombus formation. Hematologica 94, 700-711. https://doi.org/10.3324/haematol.2008.003178.

Roca, I., Akova, M., Baquero, F., et al., 2015. The global threat of antimicrobial resistance: science for intervention. New Microbe New Infect 6, 22-29. https:// doi.org/10.1016/j.nmni.2015.02.007.

Rodrigues, M., de la Torre, B.G., Andreu, D., Santos, N.C., 2013. Kinetic uptake profiles of cell penetrating peptides in lymphocytes and monocytes. Biochim. Biophys. Acta 1830 (10), 4554-4563. https://doi.org/10.1016/j.bbagen.2013.05.020.

Saravia, P., et al., 2002. Geographic and ontogenic variability in the venom of the neotropical rattlesnake Crotalus durissus: pathophysiological and therapeutic implications. Rev. Biol. Trop. 50 (1), 337-346.

Szabó, I., Bock, J., Grassmé, H., Soddermann, M., Wilker, B., Lang, F., Zoratti, M. Gulbins, E., 2008. Mitochondrial potassium channel Kv1.3 mediates Baxinduced apoptosis in lymphocytes. Proc. Natl. Acad. Sci. U. S. A. 105 (39), 14861-14866.

Serrano, S.M.T., Maroun, R.C., 2005. Snake venom serine proteinase: sequence homology vs. substrate specificity, a paradox to be solved. Toxicon 45 (8), 1115-1132. https://doi.org/10.1016/j.toxicon.2005.02.020.

Shevchenko, A., Wilm, M., Vorm, O., Mann, M., 1996. Mass spectrometric sequencing of proteins silver-staned polyacrylamide gels. Anal. Chem. 68 (5), 850-858. https://doi.org/10.1021/ac950914h.

Strateva, T., Yordanov, D., 2009. Pseudomonas aeruginosa - a phenomenon of bacterial resistance. J. Med. Microbiol. 58, 1133-1148. https://doi.org/10.1099/ jmm.0.009142-0. 
Szewczyk, A., Wojtczak, L., 2002. Mitochondria as a pharmacological target. Pharmacol. Rev. 54, 101-127. https://doi.org/10.1124/pr.54.1.101.

Teno, A.M., Vieira, C.A., Santoro, N.M., Neves, A.G., Giglio, J.R., 1990. Interchain disulfide bonds in crotamine self-association. J. Biochem. 107 (6), 821-825. https://doi.org/10.1093/oxfordjournals.jbchem.a123132.

Toyama, M.H., Carneiro, E.M., Marangoni, S., Barbosa, R.L., Corso, G., Boschero, A.C., 2000. Biochemical characterization of two crotamine isoforms isolated by a single step RP-HPLC from Crotalus durissus terrificus (South American rattlesnake) venom and their action on insulin secretion by pancreatic islets. Biochim. Biophys. Acta 1474, 56-60. https://doi.org/10.1016/S0304-4165(99) 00211-1.

Tsujimoto, Y., Shimizu, S., 2007. Role of the mitochondrial membrane permeability transition in cell death. Apoptosis 12, 835-840. https://doi.org/10.1007/s10495006-0525-7.

Valente, R.H., Novello, J.C., Marangoni, S., Oliveira, B., Pereira-da-Silva, L., Macedo, D.V., 1998. Mitochondrial swelling and oxygen consumption during respiratory state 4 induced by phospholipase A2 isoforms isolated from the South American rattlesnake (Crotalus durissus terrificus) venom. Toxicon 36, 901-913.

Vargas, L.S., Lara, M.V., Gonçalves, R., Mandredini, V., Ponce-Soto, L.A. Marangoni, S., Dal Belo, C.A., Mello-Carpes, P.B., 2014. The intrahippocampal infusion of crotamine from Crotalus durissus terrificus venom enhaces memory persistence in rats. Toxicon 85, 52-58. https://doi.org/10.1016/ j.toxicon.2014.04.017

Wallace, K.B., Starkov, A.A., 2000. Mitochondrial targets of drug toxicity. Annu. Rev. Pharmacol. Toxicol. annurev.pharmtox.40.1.353.

Wayne, P.A., 2007. Performance Standards for Antimicrobial Susceptibility Testing. Clinical and laboratory standards institute, 17.

World Health Organization (WHO), 2017. Antibiotic-resistant Priority Pathogens List. Virtual Press Conference, 2017.

Yamane, E.S., Bizerra, F.C., Oliveira, E.B., Moreira, J.T., Rajabi, M., Nunes, G.L., de Souza, A.O., da Silva, I.D., Yamane, T., Karpel, R.L., Silva Jr., P.I., Hayashi, M.A., 2013. Unraveling the antifungal activity of a South American rattlesnake toxin crotamine. Biochimie 95 (2), 231-240. https://doi.org/10.1016/ j.biochi.2012.09.019.

Yonamine, C.M., Prieto-da-Silva, A.R., Magalhães, G.S., Rádis-Baptista, G. Morganti, L., Ambiel, F.C., Chura-Chambi, R.M., Yamane, T., Camillo, M.A., 2009 Cloning of serine protease cDNAs from Crotalus durissus terrificus venom gland and expression of a functional Gyroxin homologue in COS-7 cells. Toxicon. 54 (2), 110-120. https://doi.org/10.1016/j.toxicon.2009.03.022.

Young, M.L., Bains, M., Bell, A., Hancock, R.W., 1992. Role of Pseudomonas aeruginosa outer membrane protein OprH in polymyxin and gentamicin resistance: isolation of an OprH-deficient mutant by gene replacement techniques. Antimicrob. Agents Chemother. 36, 2566-2568. https://doi.org/10.1128/ AAC. 36.11.2566. 